San Antonio Review • San Antonio Review (Volume V | Summer 2021)

\title{
You Always Demand Rain, But Only Supply Ruin
}

\author{
Jake Sheff
}

Published on: Jun 23, 2021

DOI: $10.21428 / 9 b 43 c d 98 . d 3830 a c f$

License: Creative Commons Attribution 4.0 International License (CC-BY 4.0). 


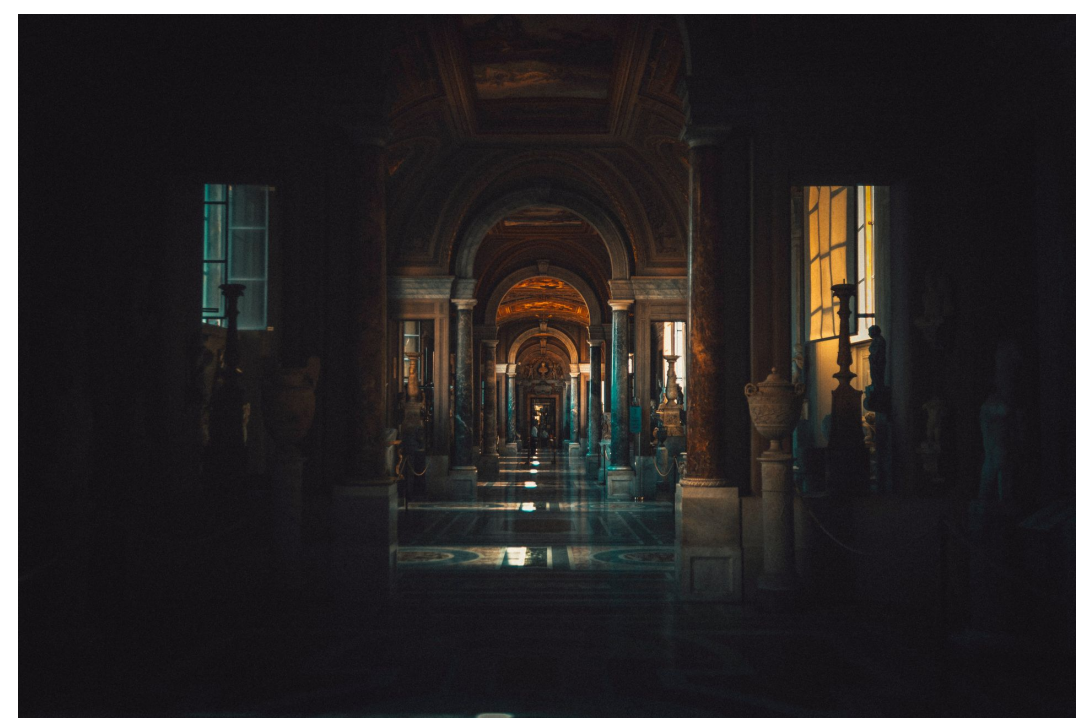

Photo by Eggor Myznik on Unsplash

Feast:

My hunger is no method actor; love,

In the beginning, laid my hunger down

On mossy music. Days unworthy of

Her gaze are days no more. It all had grown

Around her: every step a grape, to drown

In wine that went with every kind of food;

Compared to non-existence, it was good.

Milk, honey, coffee, spices; all was in

Her custody. I saw, in living bronze,

The Dying Gaul stand up. If fall was in 
The air, it failed. "She breathes, the moon responds,"

I noted; moonlight tasted of pecans

Back then. My health was none of love's concern.

She taught a lesson no one wants to learn.

Famine:

The snow is too loud for my eyes, too hot

For hearts today. Her final breath was strange,

Was sweetly strange: (I wish that tongues forgot);

You'd swear that Doctor Lister kissed her. Change

Gets paid in salt, and that's too bad: this range

Of possibilities is doggerel;

My memory spits it out, and says, "I'm full."

These candles make the coldness only seem

Forgotten. Wisdom stands by Terminus

To worship God, while hunger forms a team

With The Night Watch. Imagine nothing is,

Then look again, and nothing doesn't blaze!

A fork! A fork! My birthright just to spoon!

Let Typhoid Mary undercook the moon. 
Feast:

Tomorrow love will feed the ocean; rain

And tears and nations always fall. The time

Will serve me empathy before a grain

Of self-awareness grows. Love's paradigm

Will split in half to be my lemon-lime

Refreshment. She will slice what's never old,

Turn every nugget in distress to gold.

Love's light will still be very vertical.

Starvation is her lifeblood; I will fast

Until what's never too available -

Her last forbidden fact - is my repast.

She'll decorate the sky and flabbergast

The moon with darkling globes. Trifoliate

And pure, her rhythms will be trees of light.

Jake Sheff is a pediatrician and veteran of the US Air Force. He's married with a daughter and six pets. Poems and short stories of Jake's have been published widely. Some have even been nominated for the Best of the Net Anthology and the Pushcart Prize. His chapbook, Looting Versailles, is available from Alabaster Leaves Publishing. 